\title{
Bcr-Abl tyrosine kinase inhibitors- current status
}

\author{
Anum Mughal', Hafiz Muhammad Aslam¹, Aga Muhammad Hammad Khan², Shafaq Saleem', Ribak Umahn ${ }^{3 *}$ \\ and Maria Saleem ${ }^{4}$
}

\begin{abstract}
Bcr-Abl plays a central role in the development of chromosome positive leukaemia. Chronic Myeloid leukaemia occurs due to increase proliferation and resistance to apoptosis by Bcr-Abl positive cells. Imatinib (STI571) is the first drug in the family of Bcr-Abl tyrosine kinase inhibitors while Nilotinib (AMN107) and Dasatinib (BMS-345825) are second generation drugs that are intended to have less resistance and intolerance than imatinib. Ponatinib (AP24534) an orally active Bcr-Abl Tyrosine Kinase Inhibitor and Bafetinib (INNO-406) have efficacy against various point mutations in the Bcr-Abl kinase. 1, 3, 4 thiadiazole derivatives has also displayed moderate inhibitory action on both Abl and Src kinase family. However there are varieties of Bcr-Abl inhibitors but Nilotinib is still the frontline tyrosine kinase inhibitors.
\end{abstract}

\section{Letter to editor}

The Bcr-Abl chimeric protein is thought to play a central role in the pathogenesis of Philadelphia (Ph) chromosome-positive leukaemia, notably Chronic Myeloid Leukaemia (CML) [1]. This abnormality was discovered by Janet Rowley in 1972 and it is due to the reciprocal translocation between chromosome 9 and 22 . Three fusion proteins can be formed as a result of breakpoint in Bcr, all of which exhibit deregulated PTK activity [2-4]. Basic mechanisms that have been attributed to Bcr-Abl positive cells, particularly in CML, are increased proliferation, increased resistance to apoptosis [5-7], and an alteration of their adhesion properties $[8,9]$. Mutational analysis show that the Tyrosine Kinase activity of the protein is an absolute requirement for malignant transformation, and that it cannot be complemented by any downstream effectors $[10,11]$. For these reasons, an inhibitor of the Bcr-Abl tyrosine kinase should be an effective and selective treatment for CML.

Selective therapies are aimed for the treatment of CML because its target is well defined in contrast to other cancers of body [12]. Hundreds of protein kinases are known in human genome and a drug was required that targeted a single ATP binding site of protein kinase [13]. By blocking the binding of ATP, phosphorylation is

\footnotetext{
* Correspondence: ribakumah@hotmail.com

${ }^{3}$ Final Year Student Of Dinajpur Medical College, Dakshin Dinajpur District, West Bengal, Bangladesh

Full list of author information is available at the end of the article
}

prevented and Bcr- Abl expressing cells either have a growth disadvantage or they undergo apoptosis [7].

Imatinib (STI571) is the first drug of Bcr-Abl tyrosine kinase inhibitors that prevents ATP from binding by itself binding to $\mathrm{Abl}$ domain via six hydrogen bond interactions [14]. Hydrogen bonds involve the pyridine- $\mathrm{N}$ and backbone- $\mathrm{NH}$ of Met-318, the aminopyrimidine and side chain hydroxyl of Thr-315, the amide- $\mathrm{NH}$ and side chain carboxylate of Glu-285, the carbonyl and backbone$\mathrm{NH}$ of Asp-381, the protonated methylpiperazine with the backbone-carbonyl atoms of Ile-360 and His-361. Additionally, a number of van der Waals interactions contribute to binding [13-15]. Resistance faced by imaitinab can be subdivided into BCR independent and dependant mechanisms [16]. Dependant mechanism depend upon the duplication of BCR-ABL tyrosine kinase gene in DNA sequence leading to higher expression of pathogens [12]. Point mutation in the kinase domain of Bcr-Abl leading to disrupt in the binding site of imatinib on the tyrosine kinase, resulting in the loss of sensitivity of drug [16]. The T315I is a unique mutation because of its resistance to all approved Bcr-Abl inhibitors, prior to ponatinib [17]. It may be due to the displacement of cytosine to thiamine $(\mathrm{C}->\mathrm{T})$ base pair at 944 of the $\mathrm{Abl}$ gene. It cause the elimination of critical $\mathrm{O} 2$ molecule needed for hydrogen bonding between imatinab and Bcr-Abl kinases [12]. Most common mutation has been occurred in ATP binding and activation loop. It cause the derangement of loops as a result of which kinase domain cannot assume inactive conformation required for imatinib 
binding [16]. Bcr independent resistance occur either due to over expression of P-glycoprotein efflux pump, activation of Src family kinase or may be because of low expression, activity or polymorphism of OCT1 $[12,18]$. Solution for combating resistance is to increase the dose of imitinab, administration of multiple Abl kinase inhibitors and usage of two drugs simultaneously who have different pathways $[16,19]$. Nilotinib (AMN107) and Dasatinib (BMS-345825) are second generation drugs that are intended to have less resistance and intolerance than Imatinib [12]. Nilotinib is a selective inhibitor and binds to the inactive conformation of the Abl kinase domain, largely through lipophilic interactions and thus blocks its catalytic activity, being $10-30$ fold potent than Imatinib $[19,20]$. Nilotinib binds to kinase domain with the help of $\mathrm{H} 2$ bond interaction involving pyridyl- $\mathrm{N}$ and backbone of NH of Met-318, amino $\mathrm{NH}$ and side chain of $\mathrm{OH}$ of Thr 315, amido $\mathrm{NH}$, side chain carboxylate of Glu286 and amido carbonyl with backbone NH of Asp -381 $[21,22]$. It is effective against all type of resistances except T315I mutation. Its failure against T315I is due to the loss of an $\mathrm{H}$-bond interaction between threonine- $\mathrm{O}$ and aniline- $\mathrm{NH}$ on nilotinib and a steric clash between the isoleucine-methyl group and 2-methylphenyl phenyl group of nilotinib [19-21]. Dasatinib is multi targeted inhibitor of wild type Bcr-Abl and Src family kinases having additional inhibitory activity against downstream kinases [23]. Contrary to most Tyrosine Kinase Inhibitors, Dasatinib bind to active conformation of Abl kinase [15]. First and second generations inhibitors have provided promising results but new mutations are continuously being encountered that requires discovery of more drugs.

Bosutinib is based on a quinolone scaffold and is related to AstraZeneca quinazoline template and it also had the ability of inhibiting mutation of T3151 [20]. Ponatinib (AP24534) an orally active Bcr-Abl Tyrosine Kinase Inhibitor effective against the T315I mutation had been approved for a phase II clinical trial [24]. Bafetinib (INNO-406) with efficacy against various point mutations in the Bcr-Abl kinase, with fewer adverse effects and with narrower kinase spectra, is also in phase II clinical trials [25]. Befitinib and Imatinib has structural and binding similarities, the notable difference being hydrophobic interaction between the trifluoromethyl group and the hydrophobic pocket created by Ile-293, Leu-298, Leu-354, and Val-379 [26]. 1, 3, 4 thiadiazole derivatives has also displayed moderate inhibitory action on both Abl and Src kinases with similar binding properties as dasatinib, and are still in trials to prove a novel way to inhibit Tyrosine Kinases [27].

Although there are more potent Bcr-Abl Tyrosine Kinase Inhibitors are available, but Imatinib still remains the frontline Tyrosine Kinase Inhibitors. Nilotinib, Dasatinib,
Bosutinib and Ponatinib are approved for the treatment of Imatinib resistant or intolerant CML. The availability of highly potent tyrosine kinase inhibitors, such as nilotinib, has broadened the treatment armamentarium in CML. Nilotinib appears to overcome imatinib resistance in patients with chronic, accelerated, and blastic phase CML, producing sustained cytogenetic and haematological responses [28]. The first line data for these drugs are encouraging and suggest that some or all of them may replace Imatinib as a frontline standard BcrAbl tyrosine kinase inhibitor in the near future.

\section{Competing interests}

Authors declare they have no competing interest.

\section{Authors' contributions}

AM and HMA did manuscript drafting, AMHK, SS, RU and MS did critical review. All have given final approval of the version to be published.

\section{Author details}

${ }^{1}$ Dow Medical College, Dow University of Health Sciences, Karachi, Pakistan. ${ }^{2}$ Sindh Medical College, Dow University of Health Sciences, Karachi, Pakistan. ${ }^{3}$ Final Year Student Of Dinajpur Medical College, Dakshin Dinajpur District, West Bengal, Bangladesh. ${ }^{4}$ First Year Student of Karachi Medical And Dental College, Karachi University, Karachi, Pakistan.

Received: 11 April 2013 Accepted: 18 June 2013

Published: 20 June 2013

\section{References}

1. Nowell $P$, Hungerford D: A minute chromosome in human chronic granulocytic leukemia. Landmarks in Medical Genetics: Classic Papers with Commentaries 2004, 132(51):103.

2. Clark SS, McLaughlin J, Timmons M, Pendergast AM, Ben-Neriah Y, Dow LW, Crist W, Rovera G, Smith SD, Witte ON: Expression of a distinctive BCR-ABL oncogene in Ph1-positive acute lymphocytic leukemia (ALL). Science (New York, NY) 1988, 239(4841 Pt 1):775.

3. Konopka JB, Watanabe SM, Witte ON: An alteration of the human c-abl protein in K562 leukemia cells unmasks associated tyrosine kinase activity. Cell 1984, 37(3):1035.

4. Rowley JD: A new consistent chromosomal adnormality in chronic myelogeneus leukaemia identified by quinacrine fluorescence and Giemsa staining. Landmarks in Medical Genetics: Classic Papers with Commentaries 2004, 243(51):104.

5. Bedi A, Zehnbauer BA, Barber JP, Sharkis S, Jones R: Inhibition of apoptosis by BCR-ABL in chronic myeloid leukemia. Blood 1994, 83(8):2038-2044.

6. Cambier N, Chopra R, Strasser A, Metcalf D, Elefanty AG: BCR-ABL activates pathways mediating cytokine independence and protection against apoptosis in murine hematopoietic cells in a dose-dependent manner. Oncogene 1998, 16(3):335.

7. Cortez D, Stoica G, Pierce JH, Pendergast AM: The BCR-ABL tyrosine kinase inhibits apoptosis by activating a Ras-dependent signaling pathway. Oncogene 1996, 13(12):2589.

8. Bazzoni G, Carlesso N, Griffin JD, Hemler ME: Bcr/Abl expression stimulates integrin function in hematopoietic cell lines. J Clin Investig 1996, 98(2):521.

9. Zhao $R$, Tarone $G$, Verfaillie C: Presence of the adhesion inhibitory $\beta 1 B$ integrin isoform on CML but not normal progenitors is at least in part responsible for the decreased CML progenitor adhesion. Blood 1997, 90(Suppl 1):393a.

10. Lugo TG, Pendergast A-M, Muller AJ, Witte ON: Tyrosine kinase activity and transformation potency of bcr-abl oncogene products. Science (New York, NY) 1990, 247(4946):1079.

11. Cortez D, Kadlec L, Pendergast AM: Structural and signaling requirements for BCR-ABL-mediated transformation and inhibition of apoptosis. Mol Cell Biol 1995, 15(10):5531-5541.

12. Bixby D, Talpaz M: Mechanisms of resistance to tyrosine kinase inhibitors in chronic myeloid leukemia and recent therapeutic strategies to overcome resistance. ASH Education Program Book 2009, 2009(1):461-476. 
13. Manley $P$, Cowan-Jacob S, Buchdunger E, Fabbro D, Fendrich $G$, Furet $P$, Meyer T, Zimmermann J: Imatinib: a selective tyrosine kinase inhibitor. Eur J Cancer 2002, 38:S19-S27.

14. Asaki T, Sugiyama $Y$, Hamamoto T, Higashioka M, Umehara M, Naito H, Niwa $\mathrm{T}$ : Design and synthesis of 3-substituted benzamide derivatives as BcrAbl kinase inhibitors. Bioorg Med Chem Lett 2006, 16(5):1421-1425.

15. Eck MJ, Manley PW: The interplay of structural information and functional studies in kinase drug design: insights from BCR-Abl. Curr Opin Cell Biol 2009, 21(2):288.

16. An X, Tiwari AK, Sun Y, Ding P-R, Ashby CR, Chen Z-S: BCR-ABL tyrosine kinase inhibitors in the treatment of Philadelphia chromosome positive chronic myeloid leukemia: a review. Leuk Res 2010, 34(10):1255-1268.

17. Stein B, Douglas Smith B: Treatment options for patients with chronic myeloid leukemia who are resistant to or unable to tolerate imatinib. Clin Ther 2010, 32(5):804-820.

18. Thomas J, Wang L, Clark RE, Pirmohamed M: Active transport of imatinib into and out of cells: implications for drug resistance. Blood 2004, 104(12):3739-3745.

19. Jabbour E, Cortes J, Kantarjian H: Nilotinib for the treatment of chronic myeloid leukemia: An evidence-based review. Core evidence 2009, 4:207.

20. Manley PW, Cowan-Jacob SW, Mestan J: Advances in the structural biology, design and clinical development of Bcr-Abl kinase inhibitors for the treatment of chronic myeloid leukaemia. Biochim Biophys Acta 2005, 1754(1-2):3-13.

21. Manley PW, Stiefl N, Cowan-Jacob SW, Kaufman S, Mestan J, Wartmann M, Wiesmann M, Woodman R, Gallagher N: Structural resemblances and comparisons of the relative pharmacological properties of imatinib and nilotinib. Bioorg Med Chem 2010, 18(19):6977-6986.

22. Breccia M, Alimena G: Nilotinib: a second-generation tyrosine kinase inhibitor for chronic myeloid leukemia. Leuk Res 2010, 34(2):129-134

23. Olivieri A, Manzione L: Dasatinib: a new step in molecular target therapy. Ann Oncol 2007, 18(suppl 6):vi42-vi46.

24. O'Hare T, Pollock R, Stoffregen EP, Keats JA, Abdullah OM, Moseson EM, Rivera VM, Tang H, Metcalf CA III, Bohacek RS: Inhibition of wild-type and mutant Bcr-Abl by AP23464, a potent ATP-based oncogenic protein kinase inhibitor: implications for CML. Blood 2004, 104(8):2532-2539.

25. Kimura S, Naito H, Segawa H, Kuroda J, Yuasa T, Sato K, Yokota A, Kamitsuji Y, Kawata E, Ashihara E: NS-187, a potent and selective dual Bcr-Abl/Lyn tyrosine kinase inhibitor, is a novel agent for imatinib-resistant leukemia. Blood 2005, 106(12):3948-3954

26. Horio T, Hamasaki T, Inoue T, Wakayama T, Itou S, Naito H, Asaki T, Hayase H, Niwa T: Structural factors contributing to the Abl/Lyn dual inhibitory activity of 3-substituted benzamide derivatives. Bioorg Med Chem Lett 2007, 17(10):2712-2717.

27. Radi M, Crespan E, Botta G, Falchi F, Maga G, Manetti F, Corradi V, Mancini M, Santucci MA, Schenone S: Discovery and SAR of 1, 3, 4-thiadiazole derivatives as potent $\mathrm{Abl}$ tyrosine kinase inhibitors and cytodifferentiating agents. Bioorg Med Chem Lett 2008, 18(3):1207-1211.

28. Valent $\mathrm{P}$ : Standard treatment of $\mathrm{Ph}+\mathrm{CML}$ in 2010: how, when and where not to use what BCR/ABL1 kinase inhibitor? Eur I Clin Investig 2010, 40(10):918-931.

doi:10.1186/1750-9378-8-23

Cite this article as: Mughal et al:: Bcr-Abl tyrosine kinase inhibitorscurrent status. Infectious Agents and Cancer 2013 8:23.

\section{Submit your next manuscript to BioMed Central and take full advantage of:}

- Convenient online submission

- Thorough peer review

- No space constraints or color figure charges

- Immediate publication on acceptance

- Inclusion in PubMed, CAS, Scopus and Google Scholar

- Research which is freely available for redistribution

Submit your manuscript at www.biomedcentral.com/submit
C Biomed Central 